\title{
Leukocyte-endothelial Interaction Is Augmented by High Glucose Concentrations and Hyperglycemia in a NF-kB-dependent Fashion
}

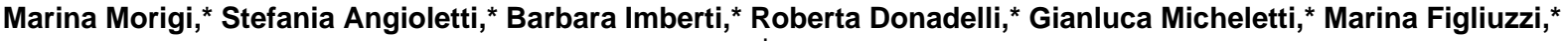 \\ Andrea Remuzzi, ${ }^{\star}$ Carla Zoja, ${ }^{\star}$ and Giuseppe Remuzzi ${ }^{\star \ddagger}$ \\ * Mario Negri Institute for Pharmacological Research, 24125 Bergamo, Italy; and ${ }^{\ddagger}$ Division of Nephrology and Dialysis, Azienda \\ Ospedaliera, Ospedali Riuniti di Bergamo, 24128 Bergamo, Italy
}

\begin{abstract}
We addressed the role of hyperglycemia in leukocyte-endothelium interaction under flow conditions by exposing human umbilical vein endothelial cells for $24 \mathrm{~h}$ to normal $(5 \mathrm{mM})$, high concentration of glucose $(30 \mathrm{mM})$, advanced glycosylation end product-albumin $(100 \mu \mathrm{g} / \mathrm{ml})$, or hyperglycemic (174-316 mg/dl) sera from patients with diabetes and abnormal hemoglobin $\mathrm{A}_{1 \mathrm{c}}(8.1 \pm 1.4 \%)$. At the end of incubation endothelial cells were perfused with total leukocyte suspension in a parallel plate flow chamber under laminar flow $\left(1.5 \mathrm{dyn} / \mathrm{cm}^{2}\right)$. Rolling and adherent cells were evaluated by digital image processing. Results showed that $30 \mathrm{mM}$ glucose significantly $(P<0.01)$ increased the number of adherent leukocytes to endothelial cells in respect to control $(5 \mathrm{mM}$ glucose; $151 \pm 19$ versus $33 \pm 8$ cells $/ \mathrm{mm}^{2}$ ). A similar response was induced by endothelial stimulation with IL-1 $\beta$, here used as positive control $\left(195 \pm 20\right.$ cells $\left./ \mathrm{mm}^{2}\right)$. The number of rolling cells on endothelial surface was not affected by high glucose level. Stable adhesion of leukocytes to glucosetreated as well as to IL-1 $\beta$-stimulated endothelial cells was preceded by short interaction of leukocytes with the endothelial surface. The distance travelled by leukocytes before arrest on $30 \mathrm{mM}$ glucose, or on IL-1 $\beta$-treated endothelial cells, was significantly $(P<0.01)$ higher than that observed for leukocytes adhering on control endothelium $(30 \mathrm{mM}$ glucose: 76.7 \pm 3.5 ; IL1 $\beta$ : $69.7 \pm 4$ versus $5 \mathrm{mM}$ glucose: $21.5 \pm 5 \mu \mathrm{m}$ ). Functional blocking of E-selectin, intercellular cell adhesion molecule-1, and vascular cell adhesion molecule-1 on endothelial cells with the corresponding mouse $\mathrm{mAb}$ significantly inhibited glucose-induced increase in leukocyte adhesion $(67 \pm 16,83 \pm 12,62 \pm 8$ versus $144 \pm 21$ cells/ $\mathrm{mm}^{2}$ ). Confocal fluorescence microscopy studies showed that $30 \mathrm{mM}$ glucose induced an increase in endothelial surface expression of E-selectin, intercellular cell adhesion molecule-1, and vascular cell adhesion molecule-1. Electro-
\end{abstract}

Part of this work was presented at the 29th Annual Meeting of the American Society of Nephrology, November 3-6, 1996, New Orleans, LA.

Address correspondence to Dr. Marina Morigi, Mario Negri Institute for Pharmacological Research, Via Gavazzeni 11, 24125 Bergamo, Italy. Phone: 39-35-319-888; FAX: 39-35-319-331; E-mail: gremuzzi@cyberg.it

Received for publication 16 May 1997 and accepted in revised form 24 February 1998.

J. Clin. Invest.

(C) The American Society for Clinical Investigation, Inc. 0021-9738/98/05/1905/11 \$2.00

Volume 101, Number 9, May 1998, 1905-1915

http://www.jci.org phoretic mobility shift assay of nuclear extracts of human umbilical vein endothelial cells (HUVEC) exposed for $1 \mathrm{~h}$ to $30 \mathrm{mM}$ glucose revealed an intense NF-kB activation. Treatment of HUVEC exposed to high glucose with the NF-kB inhibitors pyrrolidinedithiocarbamate $(100 \mu \mathrm{M})$ and tosyl-phe-chloromethylketone $(25 \mu \mathrm{M})$ significantly reduced $(P<0.05)$ leukocyte adhesion in respect to HUVEC treated with glucose alone. A significant $(P<0.01)$ inhibitory effect on glucose-induced leukocyte adhesion was observed after blocking protein kinase $\mathrm{C}$ activity with staurosporine $(5 \mathrm{nM})$. When HUVEC were treated with specific antisense oligodesoxynucleotides against PKC $\alpha$ and PKC $\epsilon$ isoforms before the addition of $30 \mathrm{mM}$ glucose, a significant $(P<0.05)$ reduction in the adhesion was also seen. Advanced glycosylation end product-albumin significantly increased the number of adhering leukocytes in respect to native albumin used as control $(110 \pm 16$ versus $66 \pm 7, P<$ 0.01). Sera from diabetic patients significantly $(P<0.01)$ enhanced leukocyte adhesion as compared with controls, despite normal levels of IL-1 $\beta$ and TNF $\alpha$ in these sera.

These data indicate that high glucose concentration and hyperglycemia promote leukocyte adhesion to the endothelium through upregulation of cell surface expression of adhesive proteins, possibly depending on NF-kB activation. ( $J$. Clin. Invest. 1998. 101:1905-1915.) Key words: adhesive molecules • AGEs • leukocyte adhesion • endothelium • flow

\section{Introduction}

Hyperglycemia has been recognized as a primary factor in the development of diabetic microvascular disease (1), but the biochemical mechanism(s) responsible for the toxicity of high glucose concentrations on vascular cell functions and their implication for cell-cell interaction in the microcirculation remain elusive. Data show that increased intracellular concentration of glucose and glycolytic intermediates trigger acute reversible changes in cellular metabolism leading to increased aldose reductase activity $(1,2)$ and to de novo synthesis of diacylglycerol responsible for protein kinase $\mathrm{C}(\mathrm{PKC})^{1}$ activation $(3,4)$. The deleterious effects of high glucose on cell function and cell-cell interaction is additionally mediated by advanced glycosylation end products (AGEs) that accumulate in the plasma and vascular tissue of diabetics $(5,6)$. AGEs are highly

1. Abbreviations used in this paper: AGEs, advanced glycosylation end products; EMSA, electrophoretic mobility shift assay; $\mathrm{HbA}_{1 \mathrm{c}}$, hemoglobin A1c; HUVEC, human umbilical vein endothelial cells; ICAM-1, intercellular cell adhesion molecule-1; ODN, oligodesoxynucleotide; PDTC, pyrrolidinedithiocarbamate; PKC, protein kinase C; TPCK, tosyl-phe-chloromethylketone; VCAM-1, vascular cell adhesion molecule-1. 
reactive substances resulting from prolonged exposure of proteins to high glucose concentration. They represent an heterologous group of compounds deriving from Amadori product, an early intermediate of the nonenzymatic reaction of glucose with free aminogroups of proteins $(1,7)$. The in vivo significance of elevated circulating and tissue AGEs as direct contributors to the accelerated vascular disease has been highlighted by in vitro studies showing that AGEs promote monocyte migration $(8,9)$ and production of cytokines $(10)$ and growth factors (8). These effects are mediated by interaction with a specific receptor, RAGE, a newly identified member of the Immunoglobulin superfamily expressed on mononuclear phagocytes as well as vascular smooth muscle cells and endothelial cells $(5,11,12)$. In endothelial cells in culture, AGEs induce cellular oxidant stress thereby increasing vascular permeability (13) and upon binding to RAGE, activate the transcriptional factor NF-kB (14). Thus high glucose concentration may contribute to the development of micro- and macro-angiopathy of diabetes by activation of distinct pathways of injury that finally concur to accelerate atherosclerosis and death.

There is now a large enough body of evidence, which is not just confined to diabetes, that credits leukocyte adhesion to vascular endothelium and their subsequent activation and migration as one of the earliest events in the development of atherosclerosis. In this context, in vitro data are available showing that monocytes isolated from diabetic patients were more adhesive to cultured human endothelium than those from normal subjects and that the adhesion was CD11-CD18 dependent (15). In vivo leukocyte accumulation in the endothelium was increased in rabbits with alloxan diabetes (16), while capillary occlusions by monocytes and granulocytes preceded destruction of capillary bed in diabetic retinopathy of rats (17). There is also evidence that in nonobese diabetic mice that spontaneously develop diabetes, upregulation of adhesion molecules and invasion of leukocytes into pancreatic islets of Langherans is followed by selective destruction of insulin-producing pancreatic $\beta$ cells (18). Of remarkable interest, treatment of these mice with antibodies against the leukocyte L-selectin, very late antigen-4 (VLA-4) and leukocyte function-associated molecule-1 (LFA-1) or endothelial mucosal addressin CAM-1 (Mad CAM-1) and intercellular adhesion molecule-1 (ICAM-1) limited leukocyte infiltration and development of spontaneous diabetes (18). In human diabetes, enhanced expression of ICAM-1 has been observed in the vascular endothelium of pancreatic islets (19), and in the retina and choroid along with upregulation of P-selectin (20).

Indirect evidence from recent studies seems to indicate that a number of abnormalities in leukocyte-endothelium interaction of diabetes can be related to hyperglycemia. Thus, in vitro, a higher than normal glucose concentration $(25 \mathrm{mM})$ induced a significant increase in monocyte binding to human aortic endothelial cells. This effect was attributed to oxidized LDL produced by endothelial cells in hyperglycemic condition that in turn would activate monocyte $\beta_{2}$ integrin (21). A preliminary report has shown that glucose alone or in association with a PKC activator increased surface expression of vascular cell adhesion molecule-1 (VCAM-1) and E-selectin on human umbilical vein endothelial cells (HUVEC; reference 22). The upregulation of adhesive molecules on cultured endothelial cells has been also documented after exposure to AGEs. Specifically, enhanced expression of ICAM-1, VCAM-1, and
E-selectin was observed on endothelial cells grown on AGEmodified matrix protein (fibronectin) while AGE-modified albumin (circulating soluble AGE protein) upregulated the expression of VCAM-1 only (23). In another study AGEs either prepared in vitro or isolated from serum of diabetic patients induced VCAM-1 expression on endothelial cells by a mechanism involving AGE binding to RAGE and the activation of the transcription factor NF-kB (14).

Compelling evidence is also available which shows that the events that modulate adhesion and infiltration of leukocytes into the endothelium are critically dependent by hemodynamic flow conditions. The flow velocity gradient near the vessel wall induces tractive forces tangential to endothelial surface (shear stress) that oppose leukocyte adhesion. The effects of flow on leukocyte-endothelium interaction have been mimicked in vitro using a parallel plate perfusion chamber and videomicroscopy (24-26). Using the in vitro replica of these dynamic conditions, it has been documented that before adhering firmly, leukocytes roll on the endothelial surface. Early molecules involved in the process of leukocyte rolling belong to the Selectin family $(27,28)$. Firm leukocyte adhesion implies an interaction of their $\beta_{1}$ and $\beta_{2}$ Integrin receptors with specific endothelial ligand, i.e., ICAM-1 and VCAM-1, belonging to the Immunoglobulin gene superfamily, whose levels are regulated by humoral mediators and flow $(26,29,30)$.

In this study we sought: $(a)$ to evaluate the effect of high glucose concentration and AGE-albumin on leukocyte interaction with HUVEC under flow conditions; $(b)$ to identify molecular determinants and intracellular events involved in glucose-induced leukocyte adhesion; and (c) to investigate whether sera from diabetic patients increased leukocyte adhesion to endothelial cells under dynamic flow conditions.

\section{Methods}

Endothelial cell culture and incubation. Endothelial cells were obtained from HUVEC by collagenase digestion according to the method of Jaffe et al. (31). The cells were grown in Medium 199 (GIBCO BRL, Gaithersburg, MD) supplemented with $10 \%$ newborn calf serum (GIBCO BRL), 10\% human serum, and antibiotics. Cultures were grown at $37^{\circ} \mathrm{C}$ in $5 \% \mathrm{CO}_{2}-95 \%$ air. Confluent HUVEC were used routinely for experiments between first and fifth passage. Cultured cells were identified as endothelial by their morphology and the presence of vWf, using indirect immunofluorescence microscopy. For the adhesion experiments HUVEC were plated on $60 \times 20-\mathrm{mm}$ plastic coverslips (Thermanox; NUNC, Inc., Naperville, IL), coated with bovine gelatin, and used $2 \mathrm{~d}$ after reaching confluence. Before adhesion assay, HUVEC were incubated for $24 \mathrm{~h}$ with M199 (containing $5 \mathrm{mM}$ glucose) plus $5 \%$ Newborn calf serum (GIBCO BRL) and $5 \%$ human serum (medium test) or with $30 \mathrm{mM}$ glucose (adding glucose to the medium test to reach $30 \mathrm{mM}$ as a final concentration; reference 32) or with medium test containing $25 \mathrm{mM}$ mannitol. Glucose used for the experiments was virtually endotoxin free (LPS < $0.001 \mathrm{ng} / \mathrm{mg}$; Sigma Chemical Co., St. Louis, MO). HUVEC stimulated for $24 \mathrm{~h}$ with recombinant human IL-1 $\beta\left(100 \mathrm{U} / \mathrm{ml} ; 5 \times 10^{7} \mathrm{U} / \mathrm{mg}\right.$ protein; Boehringer Mannheim, Mannheim, Germany) were used as positive control.

The involvement of adhesive molecules in glucose-induced leukocyte adhesion was evaluated using adhesion-blocking mouse antiE-selectin, anti-ICAM-1, or anti-VCAM-1 mAb in adhesion assay and by confocal microscopy (see below). After 24-h glucose incubation, HUVEC were treated with $10 \mu \mathrm{g} / 200 \mu \mathrm{l}$ of adhesion-blocking mouse anti-E-selectin mAb (clone 18/7; Becton Dickinson, Bedford, MA), anti-ICAM-1 (LB-2; Becton Dickinson), anti-VCAM-1 (E1/6; Bec- 
ton Dickinson), or with a mouse isotype-matched mAb (X40; Becton Dickinson) for 20 min before the adhesion assay.

To study a possible role of NF-kB in glucose-induced leukocyte adhesion, we performed two different series of experiments: (a) HUVEC were seeded in $100 \mathrm{~mm}$ plastic dishes (Falcon Labware Division, Becton Dickinson, Milan, Italy) and when confluent were exposed for $1 \mathrm{~h}$ to $30 \mathrm{mM}$ glucose. At the end of incubation nuclear proteins were extracted for electrophoretic mobility shift assay; and (b) HUVEC were pre-exposed for $1 \mathrm{~h}$ to the antioxidant and reported NF-kB inhibitor pyrrolidinedithiocarbamate (PDTC, $100 \mu \mathrm{M}$; Sigma Chemical Co. $)(33,34)$ or to the protease inhibitor tosyl-phechloromethylketone (TPCK, $25 \mu \mathrm{M}$; Sigma Chemical Co.) (34) which prevents the proteolytic degradation of $\mathrm{IkB}$, the cytoplasmic inhibitor of NF-kB (35) before the addition of $30 \mathrm{mM}$ glucose for $24 \mathrm{~h}$. To inhibit PKC activity, HUVEC were pretreated with staurosporine $(5 \mathrm{nM}$; Sigma Chemical Co.) (36) before exposure to glucose. The involvement of PKC isoforms $\alpha$ and $\epsilon$ in glucose-induced leukocyte adhesion was also evaluated by incubating HUVEC with phosphorothioate antisense oligodesoxynucleotide (ODN; TIB Molbiol, Genova, Italy) as described previously (37). We used a cationic lipid solution (lipofectin; GIBCO BRL) which enhances the ODN uptake. For transfection, HUVEC were incubated with lipofectin $(10 \mu \mathrm{g} / \mathrm{ml})$ and ODN $(1 \mu \mathrm{M})$ in serum free condition at $37^{\circ} \mathrm{C}$ for $4 \mathrm{~h}$, washed two times with medium, and then incubated with medium test and ODN $(1 \mu \mathrm{M})$ for another $4 \mathrm{~h}$. At the end of incubation fresh medium test was replaced and maintained for $20 \mathrm{~h}$ before the addition of glucose. The antisense sequences used for human PKC $\alpha$ was 5' GTT.CTC.GCT.GGT.GAG.TTT CA 3'. The sense ODN sequence 5' TG.AAA.CTC.ACC.AGC.GAG.AAC $3^{\prime}$ and a scrambled version 5' GAG.TTG.CTT.GCT.TAT.CGG.TC $3^{\prime}$ were used as controls. The antisense sequence used for PKC $\epsilon$ against the human AUG start codon was $5^{\prime}$ GCC.ATT.GAA.CAC.TAC.CAT 3'. The sense ODN sequence 5' ATG.GTA.GTG.TTC.AAT.GGC 3' was used as control.

In additional experiments HUVEC were incubated for $24 \mathrm{~h}$ with AGE-albumin $(100 \mu \mathrm{g} / \mathrm{ml})$ (14), prepared as described below, or with native HSA used as control $(100 \mu \mathrm{g} / \mathrm{ml}$; Sigma Chemical Co. $)$. Endotoxin contamination, as evaluated by E-toxate assay (Limulus amebocyte lysate; Sigma Chemical Co.) of AGE-albumin and HSA was $<0.03 \mathrm{EU} / \mathrm{ml}$, considered as negative.

Finally, in the last series of experiments HUVEC were incubated for $24 \mathrm{~h}$ with sera from diabetic patients $(n=8)$ with hyperglycemia $(174-316 \mathrm{mg} / \mathrm{dl})$ and abnormal hemoglobin A1c $\left(\mathrm{HbA}_{1 \mathrm{c}}\right)(8.1 \pm 1.4 \%)$, which measures the red blood content of the Amadori products present on the $\mathrm{NH}_{2}$-terminal valine of the hemoglobin $\beta$-chain and is indicative of the cumulative exposure of hemoglobin to blood glucose over the time period (3-4 wk) required for Amadori products to reach equilibrium (38), with sera from healthy subjects (control, $n=$ 8 ) or with IL-1 $\beta$ dissolved in control sera $(n=8)$. At the end of incubation, cells were exposed to human total leukocytes in a parallelplate flow chamber for adhesion assay.

Preparation of AGE-albumin. AGE-albumin was prepared according to the method of Takata et al. (39) with minor modifications. Briefly, HSA ( $25 \mathrm{mg} / \mathrm{ml}$; Sigma Chemical Co.) was dissolved in calcium/magnesium free PBS containing glucose $(0.5 \mathrm{M})$ in the presence of PMSF (1.5 mM; Sigma Chemical Co.), sodium azide (1 mM; Sigma Chemical Co.), and EDTA (1 mM; Merk, Darmstadt, Germany); $\mathrm{pH}$ was adjusted to between 6.8 and 7.0. The solution was sterilized using a $0.22-\mu \mathrm{m}$ filter (Sartorius Minisart, Goettingen, Germany) and incubated for $4 \mathrm{mo}$ at $37^{\circ} \mathrm{C}$ in dark. Albumin incubated in parallel without glucose was used as control. Extent of glycosylation modification was determined by absorption spectra at a concentration of $1.0 \mathrm{mg} / \mathrm{ml}$ in sodium-phosphate buffer, the absorption spectra were taken on a spectrophotometer (Cary 1E UV-Visible; Varian, Victoria, Australia) from 190 to $550 \mathrm{~nm}$ wavelength. To remove unincorporated glucose the preparations were dialyzed for $24 \mathrm{~h}$ against PBS under sterile conditions using a dialyzing membrane (GIBCO BRL).

Immunoassay for $I L-1 \beta$ and TNF $\alpha$. IL- $1 \beta$ and TNF $\alpha$ levels were measured in serum samples from diabetic patients and normal subjects by sandwich ELISA using commercially available kits (BIOTRAK; Amersham International Buckinghamshire, United Kingdom). The limits of detection of the assays were $0.1 \mathrm{pg} / \mathrm{ml}$ and 2 $\mathrm{pg} / \mathrm{ml}$ respectively. In serum samples from normal subjects levels of IL- $1 \beta$ ranged between $0-1.5 \mathrm{pg} / \mathrm{ml}$ and $\mathrm{TNF} \alpha$ was undetectable.

Leukocyte isolation. Before adhesion experiments a leukocyte suspension was prepared from human fresh venous blood collected from healthy volunteers on EDTA (final concentration $5 \mathrm{mM}$ ) and diluted with an equal volume of cold saline solution as described previously (26). The blood samples were centrifuged at $200 \mathrm{~g}$ for $10 \mathrm{~min}$ at $4^{\circ} \mathrm{C}$, the cell pellet was resuspended in 4 vol of Emagel (Behringwerke AG, Marburg, Germany), and erythrocytes were sedimented at $4^{\circ} \mathrm{C}$ for $40 \mathrm{~min}$. Supernatant was removed, centrifuged at $500 \mathrm{~g}$ for $7 \mathrm{~min}$ at $4^{\circ} \mathrm{C}$ and the pellet was washed twice by centrifugation with saline. Remaining erythrocytes were removed by ammonium chloride lysis at $4{ }^{\circ} \mathrm{C}$ and centrifugation. After this procedure the cell viability, measured by trypan blue exclusion, was $>95 \%$. Cells were then resuspended in culture medium at a final concentration of $10^{6}$ cells per milliliter.

Adhesion assay under flow conditions. For adhesion experiments we used a parallel-plate flow chamber and a perfusion system that have been described previously $(24,26)$. Briefly, the chamber is composed of two parallel surfaces, a coverslip coated with HUVEC at confluence and a flat surface machined from polymethylmethacrylate. The two surfaces are separated by a $250-\mu \mathrm{m}$ thick silicon rubber gasket, leaving a rectangular surface of $30 \times 13 \mathrm{~mm}$ exposed to flow. An inlet and outlet channel distribute the fluid uniformly along the entrance side of the adhesion surface. Shear stress levels as a function of medium flow rate was calculated as described previously (24) assuming fully developed laminar flow between the two parallel plates. After assembling with the HUVEC monolayer, the chamber is placed on the stage of an inverted phase-contrast microscope with a termostated hood to maintain the temperature at $37^{\circ} \mathrm{C}$. The microscope is connected with a video recording system (Panasonic, Osaka, Japan).

Leukocyte suspension was pumped through the chamber, at controlled flow rates, using a syringe pump (Harvard Apparatus, Inc., South Natick, MA). After initial perfusion with cell free medium at $0.6 \mathrm{dyn} / \mathrm{cm}^{2}$ for $2 \mathrm{~min}$ for equilibration, the leukocyte suspension was perfused through the chamber at $1.5 \mathrm{dyn} / \mathrm{cm}^{2}$ and images recorded thereafter. After $10 \mathrm{~min}$, cell-free medium was perfused at a flow rate of $3.0 \mathrm{dyn} / \mathrm{cm}^{2}$ for evaluation of the number of leukocytes rolling on the HUVEC surface. At this flow rate rolling leukocytes are easily distinguishable from cells freely flowing in the suspension that move much faster. After $3 \mathrm{~min}$ of perfusion at $3.0 \mathrm{dyn} / \mathrm{cm}^{2}$ several fields $(>10)$ were observed for evaluation of the number of firmly adherent cells. Images acquired during the perfusion experiments were digitized and processed on a personal computer using general purpose image processing software (NIH Image, v. 1.59; NIH, Bethesda, MD). Adherent leukocytes were identified and counted at the end of 13 min perfusion as described in detail previously $(24,26)$. The number of rolling leukocytes was evaluated by superimposition of 16 consequent frames so that rolling cells could be identified from their wake. Identification of leukocyte interaction during rolling and adhesion process was also performed manually by backward analysis of the sequences of the images recorded.

The number of cells that transmigrate across the HUVEC monolayer during the perfusion experiments was investigated as previously described (40).

Fluorescence confocal microscopy. HUVEC grown on gelatincoated coverslips were incubated for $24 \mathrm{~h}$ with control medium, $30 \mathrm{mM}$ glucose, or with IL- $1 \beta$ as positive control. At the end of the incubation, cells were fixed in $4 \%$ paraformaldehyde in PBS, $\mathrm{pH} 7.4$, for 30 min at room temperature. After three washings in PBS, cells were incubated in $0.1 \%$ bovine gelatin in PBS for 5 min to prevent nonspecific $\mathrm{mAb}$ binding. HUVEC were then incubated with $1 \mu \mathrm{g} / 100 \mu \mathrm{l}$ anti-E-selectin, anti-ICAM-1, and anti-VCAM-1 mAb for $1 \mathrm{~h}$ at room temperature. Washing with $0.1 \%$ bovine gelatin, three times for $5 \mathrm{~min}$, was followed by addition of a 1:10 dilution of FITC-conjugated 
goat anti-mouse $\mathrm{F}\left(\mathrm{ab}^{\prime}\right) 2$ fragments (Techno Genetics, Milan, Italy) for $45 \mathrm{~min}$ at room temperature. Control experiments were carried out with FITC-conjugated Ab alone.

Coverslips were washed, mounted with $1 \% N$-propyl-gallate in $50 \%$ glycerol, $0.1 \mathrm{M}$ Tris- $\mathrm{HCl}, \mathrm{pH} 8$, and examined under a confocal inverted microscope (InSight plus; Meridian Instruments, Inc., Okemos, MI). Representative fields of resting or stimulated HUVEC were digitized with 256 gray levels and printed using a film printer (Montage, FR2 film recorder; Presentation Technologies, Sunnyvale, CA).

Preparation of nuclear extracts and electrophoretic mobility shift assay (EMSA). Nuclear extracts were prepared according to Satriano and Schlondorff (41) with minor modifications. Cells, after washing with PBS, were harvested and resuspended in $1.5 \mathrm{ml}$ of hypotonic buffer A (10 mM Hepes, pH 7.6, $15 \mathrm{mM} \mathrm{KCl,} 2 \mathrm{mM} \mathrm{MgCl} 2,0.1 \mathrm{mM}$ EDTA, $1.0 \mathrm{mM}$ dithiothreitol-DTT; Sigma Chemical Co.; and $0.2 \%$ Nonidet P-40; Boehringer Mannheim). After incubating for $5 \mathrm{~min}$ on ice, the homogenate was centrifuged at $650 \mathrm{~g}$ and the pellet was then washed once with buffer A. The resulting nuclear pellet was resuspended by gentle pipetting in $100 \mu \mathrm{l}$ buffer $\mathrm{C}(25 \mathrm{mM}$ Hepes, $50 \mathrm{mM}$ $\mathrm{KCl}, 0.1 \mathrm{mM}$ EDTA, pH 8.0, $1.0 \mathrm{mM}$ DTT, 10\% [vol/vol] glycerol) and $0.4 \mathrm{M} \mathrm{NaCl}$. This suspension was incubated for $45-60 \mathrm{~min}$ at $4{ }^{\circ} \mathrm{C}$ followed by centrifugation at $18,000 \mathrm{~g}$ for $10 \mathrm{~min}$. The supernatant collected (nuclear extract) was divided into aliquots and stored at $-70^{\circ} \mathrm{C}$ for subsequent use. To minimize proteolysis, all buffers contained $1.0 \mathrm{mM}$ Pefabloc, aprotinin ( $15 \mu \mathrm{g} / \mathrm{ml}$; Sigma Chemical Co.), leupeptin $(0.5 \mu \mathrm{g} / \mathrm{ml}$; Sigma Chemical Co. $)$. Protein concentrations were determined by the Bradford assay using the Bio-Rad protein assay reagent (Bio-Rad Laboratories, Richmond, CA).

The kB DNA sequence of the immunoglobulin gene was used for the EMSA (5'-CCGGTCAGAGGGGACTTTCCGAGACT). The core $\mathrm{kB}$ sequence is underlined. Oligonucleotides were synthesized (Life Technologies/GIBCO-BRL, San Giuliano Milanese, Italy) and annealed. Probe DNA (with $5^{\prime}$ overhangs) was end-labeled by the kleenow enzyme with $\alpha\left[{ }^{32} \mathrm{P}\right] \mathrm{dCTP}$, and separated from unincorporated nucleotides over a G-50 Sephadex column (Pharmacia Fine Chemicals, Uppsala, Sweden).

Nuclear extracts $(2 \mu \mathrm{g})$ were incubated with $50 \mathrm{kcpm}$ of ${ }^{32} \mathrm{P}$-labeled NF-kB oligonucleotide in binding reaction mixture $(10 \mathrm{mM}$ Tris- $\mathrm{HCl}$, $\mathrm{pH}$ 7.5, $80 \mathrm{mM} \mathrm{NaCl}, 1 \mathrm{mM}$ EDTA, $1 \mathrm{mM}$ DTT, $5 \%$ glycerol, $1.5 \mu \mathrm{g}$ of poly [dI-dC]) in a final volume of $15 \mu \mathrm{l}$. After $30 \mathrm{~min}$ on ice, the protein-DNA complexes were resolved on a nondenaturing $6 \%$ polyacrylamide gel in $0.5 \times$ Tris-borate-EDTA buffer and run at $200 \mathrm{~V}$ for $1.5 \mathrm{~h}$ at room temperature. Gels were then dried and subjected to autoradiography for analysis.

In competition studies, a 1,000-fold molar excess of unlabeled oligonucleotide was added to the binding reaction mixture as indicated, before the addition of the labeled $\mathrm{kB}$ probe. In other experiments, to confirm the specificity of binding reaction, an excess unlabeled oligonucleotide containing an altered sequence of the consensus NF-kB sequence (5'-CCGGTCAGAATTCACTTTCCGAGACT; the altered sequence of the mutated DNA sequence is underlined) was added to the binding reaction mixture before the addition of the labeled $\mathrm{kB}$ probe.

Statistical analysis. Results are expressed as mean \pm SEM. Statistical analysis was performed using paired Student's $t$ test and one-way ANOVA followed by the Dunnet or Duncan test for multiple comparisons, as appropriate (42). Statistical significance was defined as $P<$ 0.05 .

\section{Results}

Effect of high glucose concentration on leukocyte interaction with HUVEC under flow conditions. Rolling and adherent leukocytes per unit surface area of endothelial layer, preexposed for $24 \mathrm{~h}$ to $5 \mathrm{mM}$ glucose (control), $30 \mathrm{mM}$ glucose or IL-1 $\beta(100 \mathrm{U} / \mathrm{ml})$ at the end of perfusion are reported in Fig. 1. Exposure of HUVEC to $30 \mathrm{mM}$ glucose for $24 \mathrm{~h}$ did not affect the number of rolling leukocytes per $\mathrm{mm}^{2}$, as compared with control HUVEC ( $6 \pm 3$ versus $0.5 \pm 0.2$ cells $/ \mathrm{mm}^{2}$; Fig. $1 A$ ). IL-1 $\beta$ activation, as expected, showed important leukocyte rolling on the endothelial surface $\left(48 \pm 9\right.$ cells $\left./ \mathrm{mm}^{2}, P<0.01\right)$.

High glucose exposure induced a significant $(P<0.01)$ increase in the number of leukocytes adhering to HUVEC as compared with control cells $\left(151 \pm 19\right.$ versus $33 \pm 8$ cells $/ \mathrm{mm}^{2}$; Fig. $1 B$ ). A similar response was elicited by IL- $1 \beta$, which is one of the most potent inducers of endothelial cell adhesive properties $\left(195 \pm 20\right.$ cells $/ \mathrm{mm}^{2}, P<0.01$ versus $5 \mathrm{mM}$ glucose). A comparable increase in leukocyte adhesion was observed when HUVEC were incubated with $30 \mathrm{mM}$ glucose for a more prolonged period of time, i.e., 7 days (data not shown). Fig. 2 depicts digitized images from a representative experiment at
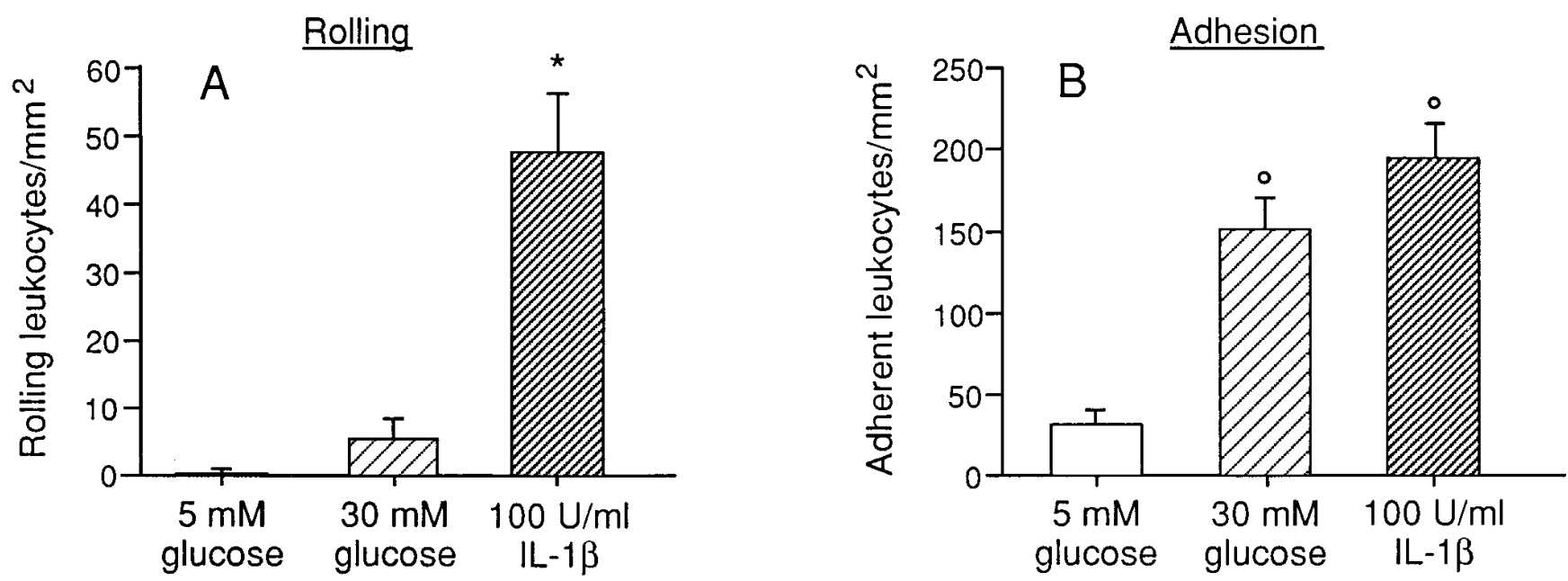

Figure 1. Rolling $(A)$ and adherent $(B)$ leukocytes on normal or high glucose-stimulated HUVEC under conditions of flow. HUVEC were incubated for $24 \mathrm{~h}$ with $5 \mathrm{mM}$ or $30 \mathrm{mM}$ glucose. HUVEC activated with IL-1 $\beta(100 \mathrm{U} / \mathrm{ml})$ were used as positive control. Leukocyte rolling and adhesion were measured at the end of the perfusion (see Methods). Data are expressed as mean \pm SEM. *P<0.01 versus $5 \mathrm{mM}$ and $30 \mathrm{mM}$ glucose; ${ }^{\circ} P<0.01$ versus $5 \mathrm{mM}$ glucose. 

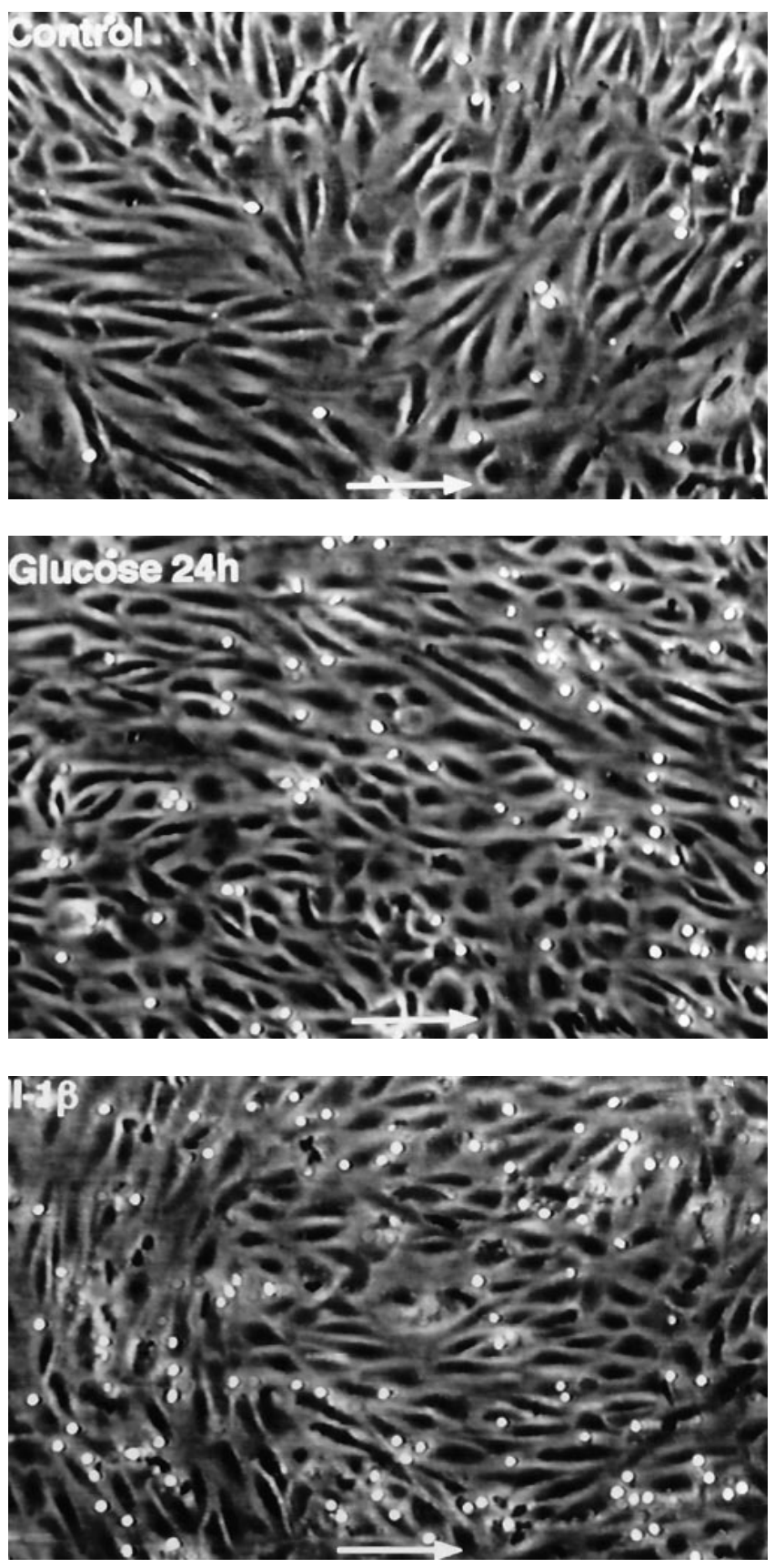

Figure 2. Effect of glucose on leukocyte adhesion to endothelial cells under flow conditions. HUVEC were incubated for $24 \mathrm{~h}$ with control medium (5 mM glucose), $30 \mathrm{mM}$ glucose or activated with IL-1 $\beta$ (100 $\mathrm{U} / \mathrm{ml})$. Here are represented digitized images of total leukocytes adherent on HUVEC at the end of the perfusion in the parallel-plate flow chamber.

the end of leukocyte perfusion. A limited number of leukocytes firmly adhered to control HUVEC, while a marked increase in leukocyte adhesion was observed on endothelial cells exposed for $24 \mathrm{~h}$ to $30 \mathrm{mM}$ glucose. Similar adhesion was observed with IL-1 $\beta$ here used as positive control.

The result that high glucose induced enhancement of leukocyte adhesion to HUVEC without affecting leukocyte rolling is in contrast with the general view that rolling is the first step for firm adhesion of circulating cells (43). Therefore we investigated whether cells rolling on the endothelial surface did actually arrest within the field of view of the microscope. Reviewing all the recorded sequences for the entire perfusion intervals, we identified each rolling cell entering the field and we followed these cells to determine whether they adhered on endothelial surface or continuously rolled exiting from the microscope field. We found that all rolling cells did not arrest within the field either on HUVEC pre-exposed to normal or high glucose concentration, as well as on IL-1 $\beta$-activated HUVEC. The total number of rolling leukocytes identified during the entire 10-min perfusions are reported in Fig. $3 \mathrm{~A}$. According to the data obtained at the end of perfusion (Fig. $1 A$ ), low number of rolling cells was identified during the perfusion experiment in HUVEC pretreated with normal or high glucose concentration, while IL-1 $\beta$ increased significantly the number of rolling cells ( $5 \mathrm{mM}$ glucose: $25 \pm 5$, and $30 \mathrm{mM}$ glucose: $35 \pm 5$ versus IL-1 $\beta$ : $207 \pm 18$ cells $\left./ \mathrm{mm}^{2}, P<0.01\right)$. Since rolling cells entering the field of view never arrested, we then examined which kind of interaction characterized those cells that actually arrested to form stable adhesion. All recorded sequences were reviewed once again backwards to identify adherent cells and then to measure the distance travelled by these cells during the rolling phase that precedes firm adhesion. Rolling motion of these cells was clearly distinguishable since at this flow rate, free-flowing cells move faster than rolling cells. These evaluations allowed to establish that, in the three experimental conditions, all cells that firmly adhered to the endothelial surface did interact with endothelium before arrest, but only for a short distance. The average distance travelled by cells before firm adhesion is reported in Fig. $3 \mathrm{~B}$. A graphic representation of this phenomenon in a representative experiment is reported in Fig. 4. Exposure of HUVEC to high glucose concentration enhanced the averaged distance travelled by leukocytes before adhesion, at a similar extent than IL-1 $\beta$, in respect to control HUVEC (30 mM glucose: 76.7 \pm 3.5 ; IL1 $\beta$ : $69.7 \pm 4$ versus $5 \mathrm{mM}$ glucose: $21.5 \pm 5 \mu \mathrm{m}, P<0.01)$.

To rule out the possibility that glucose-induced leukocyte adhesion were secondary to changes in osmolality caused by high glucose, we exposed HUVEC to $25 \mathrm{mM}$ mannitol for $24 \mathrm{~h}$. Results showed that leukocyte adhesion on HUVEC exposed to high concentration of mannitol was comparable to control cells ( $46 \pm 8$ versus $47 \pm 5$ cells $/ \mathrm{mm}^{2}$ ).

We also examined the effect of glucose on leukocyte transmigration. High glucose concentration did not affect transendothelial migration of adherent leukocytes which was similar to that observed in control cells that averaged $5.4 \pm 1$ versus $3.7 \pm 0.8$ cells $/ \mathrm{mm}^{2}$, respectively. In contrast IL-1 $\beta$ stimulation of HUVEC promoted significantly higher number of transmigrating leukocytes which averaged $17.5 \pm 2.4$ cells $/ \mathrm{mm}^{2}(P<$ 0.01 versus $5 \mathrm{mM}$ and $30 \mathrm{mM}$ glucose).

Endothelial surface adhesive proteins involved in leukocyte adhesion. To identify the molecular determinants of glucoseinduced leukocyte adhesion to endothelial cells under flow conditions, HUVEC exposed for $24 \mathrm{~h}$ to $30 \mathrm{mM}$ glucose were incubated with the adhesion blocking $\mathrm{mAb}$ anti-E-selectin, anti-ICAM-1, and anti-VCAM-1 immediately before the adhesion assay. As shown in Fig. 5, leukocyte adhesion on HUVEC exposed to high level of glucose was enhanced significantly $(P<0.01)$ as compared with $5 \mathrm{mM}$ glucose $(144 \pm 21$ versus $49 \pm 5$ cells $\left./ \mathrm{mm}^{2}\right)$. mAb anti-ICAM-1 significantly inhibited leukocyte adhesion to HUVEC incubated with $30 \mathrm{mM}$ 

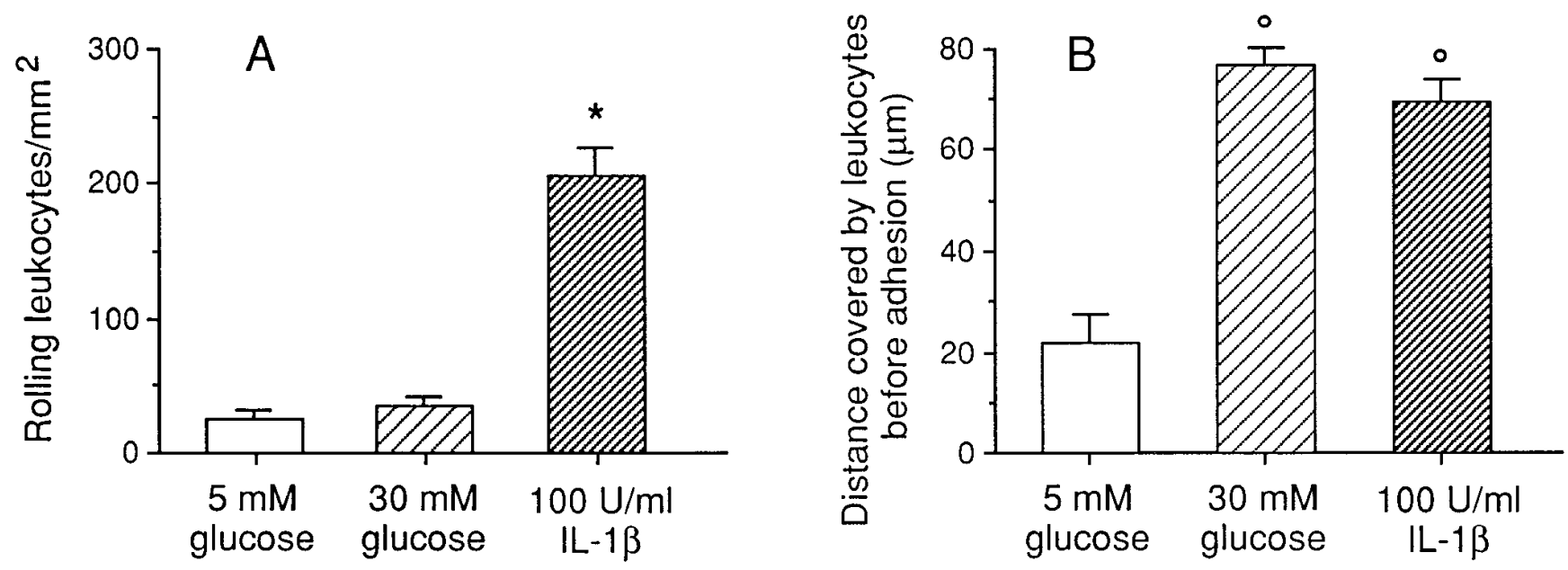

Figure 3. Total number of continuously rolling leukocytes on endothelial cells within the microscope field during the entire 10 min perfusion time $(A)$. Distance covered by adhering leukocytes before stable arrest on endothelial surface $(B)$. HUVEC were incubated with $5 \mathrm{mM}$ glucose (control), $30 \mathrm{mM}$ glucose or activated with IL-1 $\beta(100 \mathrm{U} / \mathrm{ml})$ for $24 \mathrm{~h}(A$ and $B)$. Data are expressed as mean \pm SEM. $* P<0.01 \mathrm{versus} 5 \mathrm{mM}$ and $30 \mathrm{mM}$ glucose; ${ }^{\circ} \mathrm{P}<0.01$ versus $5 \mathrm{mM}$ glucose.

glucose $\left(83 \pm 12\right.$ cells $/ \mathrm{mm}^{2}, P<0.01$ versus $30 \mathrm{mM}$ glucose $)$. Functional blocking of E-selectin and VCAM-1 had even a more inhibitory effect on glucose-induced leukocyte adhesion with the number of adhering leukocytes ranging on average $67 \pm 16$ and $62 \pm 8$ cells $/ \mathrm{mm}^{2}(P<0.01$ versus $30 \mathrm{mM}$ glucose $)$, respectively. Treatment with irrelevant $\mathrm{mAb}$ did not modify high glucose-induced leukocyte adhesion $\left(135 \pm 4\right.$ cells $\left./ \mathrm{mm}^{2}\right)$.

\section{MICROSCOPE FIELD}

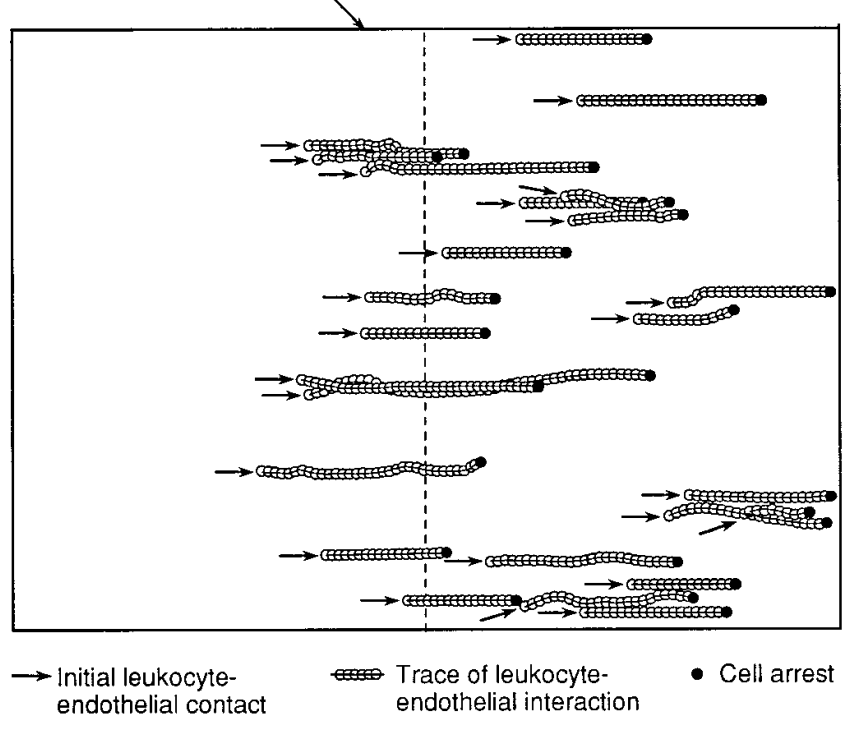

Figure 4. Digitally derived evaluation of leukocyte interaction with endothelial surface before stable adhesion. Images of a representative microscope field were analyzed to digitally trace the cell position during the rolling phase that precedes stable adhesion. Only cells adhering in the right half of the images were analyzed in each frame. All adherent cells came in contact with the endothelial surface within the microscope field. None of the cells continuously rolling stopped in the field during the perfusion interval.
The adhesive molecules involved in high glucose-induced leukocyte adhesion to endothelial cells were further characterized by confocal fluorescence microscopy. As shown in Fig. 6, HUVEC exposed to $30 \mathrm{mM}$ glucose exhibited increased expression of E-selectin, ICAM-1, and VCAM-1 on the luminal surface in respect to control cells ( $5 \mathrm{mM}$ glucose). IL- $1 \beta$, used as a positive control, induced a strong intensity staining on cell surface for all the adhesive molecules studied. Control experiments carried out in the absence of the primary antibodies showed no fluorescence on high glucose-stimulated HUVEC (not shown).

Effect of high glucose concentration on $N F-k B$ activation. To investigate whether high glucose concentration activated the transcriptional factor NF-kB, which is known to be involved in the upregulation of adhesive molecules, HUVEC

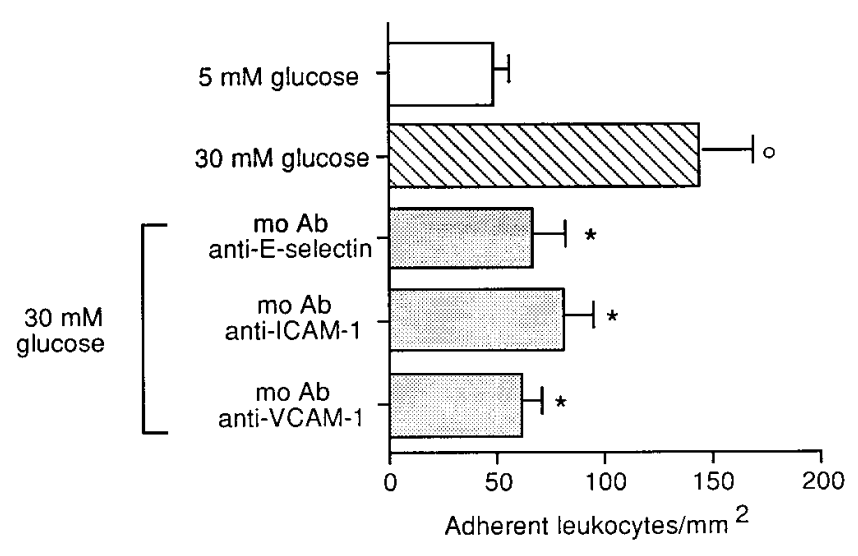

Figure 5. Effect of mAb anti-E-selectin, anti-ICAM-1 or antiVCAM-1 on glucose-induced leukocyte adhesion on endothelial cells. Before the adhesion assay $30 \mathrm{mM}$ glucose-treated HUVEC were incubated for $20 \mathrm{~min}$ with $\mathrm{mAb}$ anti-E-selectin, anti-ICAM-1, or anti-VCAM-1. Data are expressed as mean \pm SEM. ${ }^{\circ} P<0.01$ versus $5 \mathrm{mM}$ glucose; $* P<0.01$ versus $30 \mathrm{mM}$ glucose. 

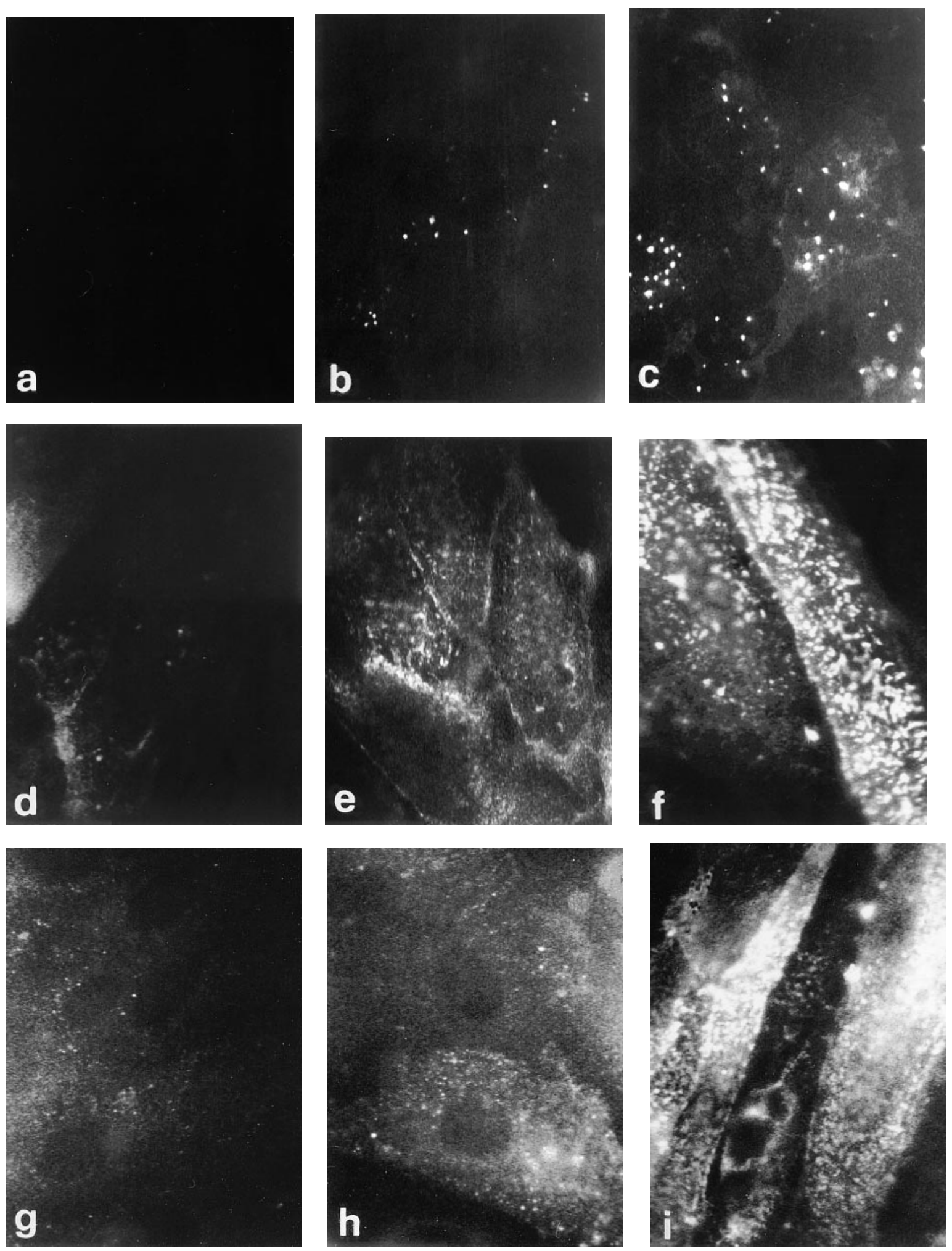

Figure 6. Confocal micrographs of control (glucose $5 \mathrm{mM} ; a, d$, and $g$ ), glucose $30 \mathrm{mM}(b, e$, and $h$ ), and IL-1 $\beta$-treated HUVEC ( $c, f$, and $i$ ) stained for E-selectin $(a-c)$, ICAM-1 $(d-f)$, and VCAM-1 $(g-i)$. After 24-h incubation with $30 \mathrm{mM}$ glucose, HUVEC showed an increased expression of E-selectin $(b)$ in respect to control cells $(a)$; IL-1 $\beta$-treated cells were used as the positive control $(c)$. Control HUVEC stained for ICAM-1 $(d)$ showed a weak fluorescence. In glucose-treated HUVEC $(e)$ staining for ICAM-1 produced a stronger, diffuse granular pattern; IL-1 $\beta$-treated cells were used as the positive control $(f)$. Expression of VCAM-1 increased in glucose-treated HUVEC $(h)$ in respect to control cells $(g)$; IL-1 $\beta$-treated cells were used as the positive control $(i)$. 


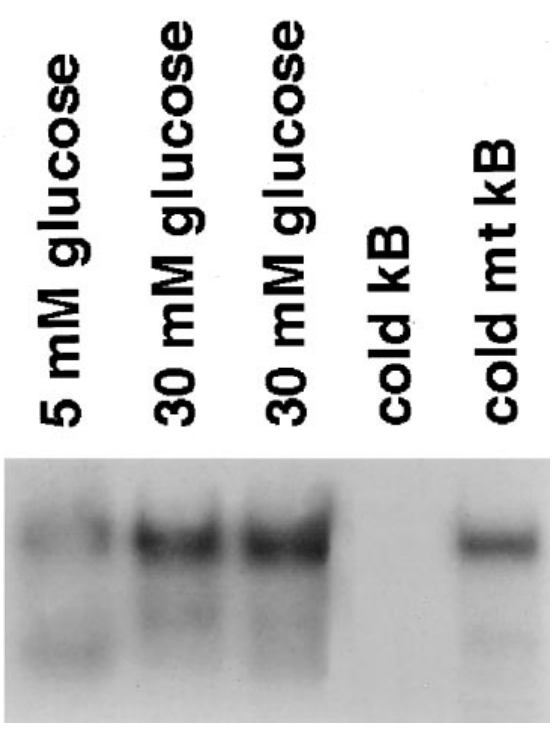

Figure 7. Electrophoretic mobility shift analysis for NF-kB activity in nuclear extracts from HUVEC exposed for $1 \mathrm{~h}$ to $5 \mathrm{mM}$ glucose (control) or $30 \mathrm{mM}$ glucose. To demonstrate the specificity of binding of the NF-kB oligonucleotide, 1,000-fold molar excess unlabeled NF-kB (cold) and unlabeled kB-mutant oligonucleotide (cold $m t \mathrm{kB}$ ) were used to compete with the labeled NF-kB probe for binding to glucose-induced nuclear proteins.

were exposed to $30 \mathrm{mM}$ glucose for $1 \mathrm{~h}$. As shown in Fig. 7, EMSA of nuclear extracts harvested from control cells $(5 \mathrm{mM}$ glucose) demonstrated little constitutive binding to an oligonucleotide containing the consensus NF-kB recognition sequence. After treatment with $30 \mathrm{mM}$ glucose an intensely labeled complex was observed. This NF-kB like band could effectively be competed out with an excess unlabeled (cold $k B)$ NF-kB oligonucleotide (Fig. 7). In contrast, the mutated $\mathrm{kB}$ sequence (cold $m t \mathrm{kB}$ ) was far less efficient in displacing labeled NF-kB binding DNA sequences indicating kB-specific DNA binding of the nuclear protein extracts (Fig. 7).

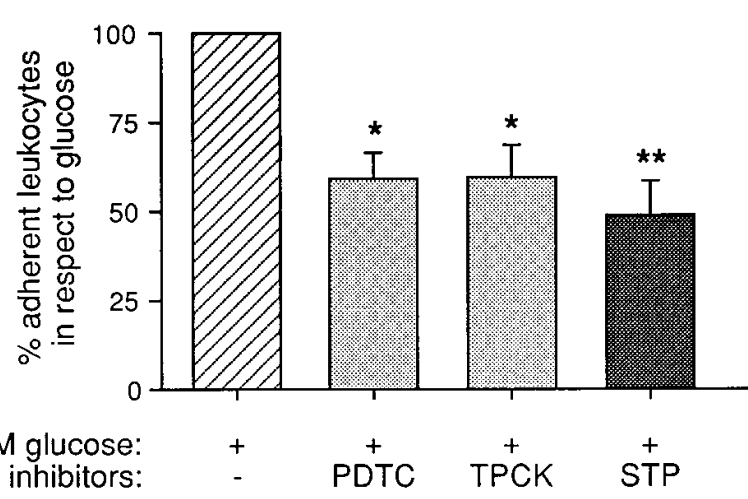

Figure 8. Effect of NF-kB and PKC inhibitors on glucose-induced leukocyte adhesion to HUVEC under flow conditions. Before the adhesion assay, HUVEC were pretreated with the NF-kB inhibitors PDTC $(100 \mu \mathrm{M})$ and TPCK $(25 \mu \mathrm{M})$ or the PKC inhibitor staurosporine $(5 \mathrm{nM}) 1 \mathrm{~h}$ before the addition of $30 \mathrm{mM}$ glucose. Data (mean \pm SEM) are expressed as percent of adherent leukocytes in respect to $30 \mathrm{mM}$ glucose considered as $100 \%$. ${ }^{*} P<0.05$, $* * P<0.01$ versus $30 \mathrm{mM}$ glucose.
Role of NF-kB and PKC on glucose-induced leukocyte adhesion. To evaluate a possible role of NF-kB and PKC activation on high glucose-induced leukocyte adhesion, HUVEC were pretreated with the NF-kB inhibitors PDTC and TPCK or with the PKC inhibitor staurosporine before the addition of $30 \mathrm{mM}$ glucose. As shown in Fig. 8, both PDTC and TPCK significantly $(P<0.05)$ reduced leukocyte adhesion in respect to HUVEC treated with glucose alone. A significant $(P<0.01)$ inhibitory effect on glucose-induced leukocyte adhesion was also observed when HUVEC were pretreated with staurosporine. We then examined whether a specific downregulation of PKC $\alpha$ and PKC $\epsilon$ isoforms with antisense ODNs influenced the glucose-induced leukocyte adhesion (Fig. 9). Antisense ODNs against PKC $\alpha$ and PKCe significantly $(P<0.05)$ reduced leukocyte adhesion on endothelial cells exposed to $30 \mathrm{mM}$ glucose as compared with sense ODNs or scrambled used as controls.

Effect of AGE-albumin on leukocyte adhesion to HUVEC under flow conditions. Fig. 10 shows the effect of AGE-albu$\min (100 \mu \mathrm{g} / \mathrm{ml})$ on leukocyte adhesion to HUVEC under flow conditions. AGE-albumin significantly increased leukocyte adhesion in respect to native albumin, used as control $(110 \pm 16$ versus $66 \pm 7$ cells $\left./ \mathrm{mm}^{2}, P<0.01\right)$. As also shown in Fig. 10, the
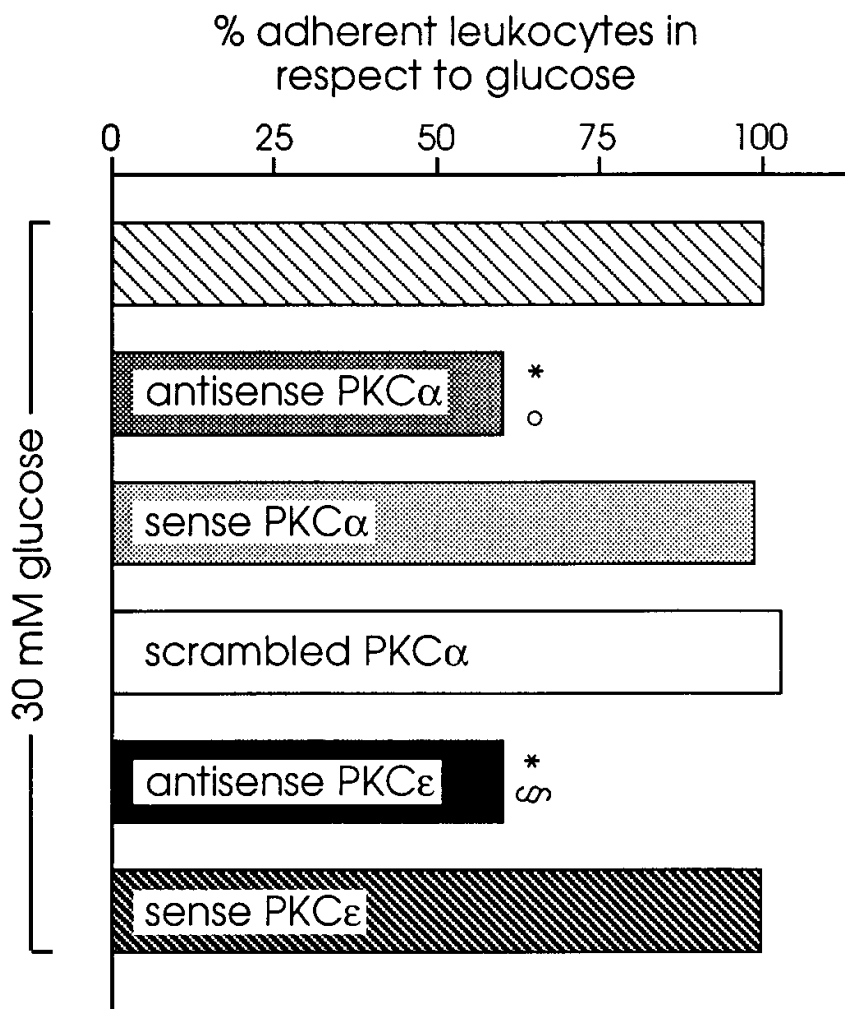

Figure 9. Effect of antisense ODN against PKC $\alpha$, sense and scrambled ODNs, or antisense against PKC $\epsilon$ and sense ODN on glucoseinduced leukocyte adhesion to HUVEC under flow conditions. Before the adhesion assay, HUVEC were pretreated with the antisense, sense or scrambled ODN $1 \mathrm{~h}$ before the addition of $30 \mathrm{mM}$ glucose. Data (mean \pm SE) are expressed as percent of adherent leukocytes in respect to $30 \mathrm{mM}$ glucose considered as $100 \%$. $* P<0.05$ versus $30 \mathrm{mM}$ glucose; ${ }^{\circ} P<0.05$ versus sense and scrambled $\mathrm{PKC} \alpha ;{ }^{\S} P<0.05$ versus sense PKC $\epsilon$. 


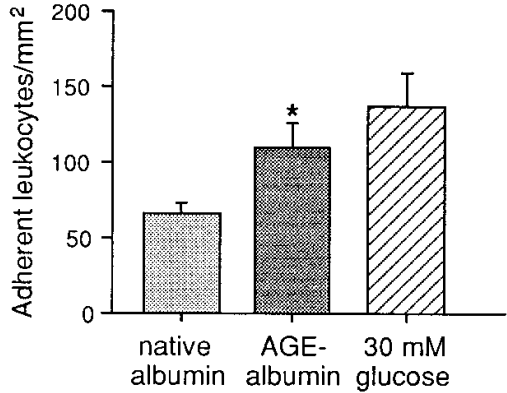

adhesive response elicited by AGE-albumin was similar to that induced by $30 \mathrm{mM}$ glucose $\left(137 \pm 22\right.$ cells $\left./ \mathrm{mm}^{2}\right)$.

Effect of sera from diabetic patients on leukocyte adhesion to HUVEC under flow conditions. For $24 \mathrm{~h}$, we exposed HUVEC to sera from control or diabetic patients with hyperglycemia (174-316 mg/dl) and abnormal level of $\mathrm{HbA}_{1 \mathrm{c}}(8.1 \pm 1.4 \%)$. At the end of incubation, we performed the adhesion assay with leukocyte suspension obtained from normal subjects. Within each experiment one serum sample from a diabetic patient and a control serum sample from an healthy volunteer

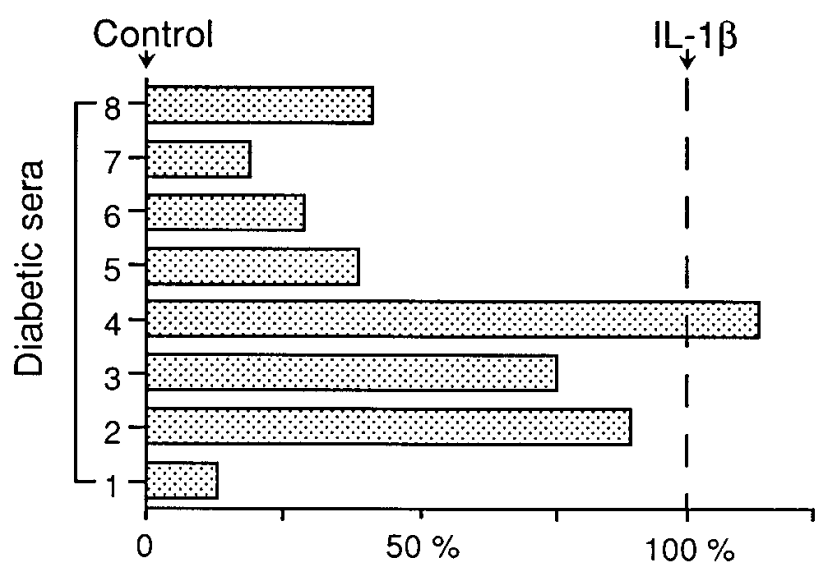

Percent increase in adherent leukocytes $/ \mathrm{mm}^{2}$ above controls. Difference was normalized using the percent increase induced by $\mathrm{IL}-1 \beta$ within each experiment.

Figure 11. Effect of endothelial incubation with sera from diabetic patients on leukocyte adhesion under flow conditions. HUVEC were incubated for $24 \mathrm{~h}$ with sera from diabetic patients, with sera from healthy subjects (control) or with IL- $1 \beta$ dissolved in control sera. At the end of incubation, an adhesion assay was performed with total leukocyte suspension obtained from normal subjects. For each experiment, an index of the percent increase in leukocyte adhesion $(A)$ on endothelial cells exposed to diabetic sera was calculated using the formula: $\mathrm{A}(\%)=(\mathrm{DS}-\mathrm{C}) /(\mathrm{IL}-\mathrm{C}) \times 100$, where $D S$ is the number of adherent leukocytes $/ \mathrm{mm}^{2}$ on HUVEC exposed to diabetic sera; $C$ is the number of adherent leukocytes $/ \mathrm{mm}^{2}$ on HUVEC exposed to control sera; and $I L$ is the number of adherent leukocytes $/ \mathrm{mm}^{2}$ on HUVEC activated with IL- $1 \beta . A(\%)$ equals $0 \%$ if there is no increase in cell adhesion above control value and equals $100 \%$ if increase in cell adhesion is equal to that induced by IL-1 $\beta$. Diabetic sera significantly $(P<0.01)$ enhanced leukocyte adhesion on endothelial cells in respect to control sera. were used, together with a positive control, i.e., IL-1 $\beta$ activated HUVEC. Because of the variability in response that is observed for different HUVEC cultures, we normalized the changes in cell adhesion as reported in Fig. 11. All diabetic sera significantly $(P<0.01)$ enhanced leukocyte adhesion to HUVEC over the corresponding control value, some serum samples induced leukocyte adhesion comparable to that induced by HUVEC activation with IL-1 $\beta$. Serum levels of IL$1 \beta$ and TNF $\alpha$ in diabetic patients were within the normal range (IL-1 $\beta$ : $0.190 \pm 0.02 \mathrm{pg} / \mathrm{ml} ; \mathrm{TNF} \alpha:<2 \mathrm{pg} / \mathrm{ml}$ ) thus excluding a role for these cytokines in enhanced leukocyte adhesion.

\section{Discussion}

This study shows, for the first time, that a higher-than-normal concentration $(30 \mathrm{mM})$ of glucose induced leukocyte adhesion to cultured endothelial cells under flow conditions typical of postcapillary venule circulation. The adhesive response elicited by glucose was quite similar to that of IL- $1 \beta$, one of the most potent inducers of leukocyte-endothelial cell adhesiveness so far known (30).

The selective effect of high glucose on leukocyte adhesion, and not on rolling, on the endothelial surface prompted us to carefully evaluate the dynamic interaction between leukocytes and the endothelial surface. Using video microscopy technique we documented that rolling cells do not firmly adhere, but rather continuously move on the endothelial surface. This was observed on control HUVEC as well as on HUVEC exposed to high glucose or to IL-1 $\beta$. On the contrary, cells that actually adhere, come in contact with the endothelial surface for a short distance before stable adhesion. On control HUVEC leukocytes travelled for an average distance of about $21 \mu \mathrm{m}$ in contact with the endothelial surface before arresting. On HUVEC exposed to high glucose, this distance importantly increased to more than $76 \mu \mathrm{m}$ in average, similar to what observed on IL-1 $\beta$ stimulated HUVEC. These observations indicate that leukocyte-endothelial interaction is more complex than what has been derived so far. In details, they suggest that the weak interactions that characterize rolling cells may give place to two different patterns, one resulting in continuous cell movement without a subsequent adhesion, while another interaction of circulating cells with endothelium is requested for effective cell arrest. It is tempting to speculate that these two phenomena depend from different adhesion molecules expressed on the surface of leukocytes and endothelial cells. Our data show that high glucose exposure to HUVEC affected the second pattern of initial leukocyte-endothelial interaction we have identified, and resulted in increased cell adhesion.

Our in vitro results of glucose-induced leukocyte adhesion are in agreement with data obtained in animal models of diabetes showing capillary occlusion by leukocytes associated with extravascular macrophage accumulation (16-18). Evidence derived from intravital microscopy studies also documented that, in rats made diabetic by streptozotocin injection, the diabetic state induced lower venular shear rates and an increased number of rolling leukocytes in mesenteric venules as compared with nondiabetic animals (44). In response to ischemia-reperfusion an exaggerated leukocyte adhesion, dependent by CD11/CD18 ICAM-1 interaction, and a remarkable transmigration was also observed. 
There are some conflicting results in the literature on the subject of glucose-induced upregulation of adhesive molecules. In one study, $20 \mathrm{mM}$ concentration of glucose induced increased surface expression of VCAM-1 and E-selectin on HUVEC, via activation of PKC (22). By contrast, in another study, under static conditions, increased binding of monocytes to human aortic endothelial cells induced by elevated glucose was not associated with enhanced expression of adhesive molecules (21). Our finding that the functional blocking of E-selectin, ICAM-1, and VCAM-1 with the respective antibodies significantly reduced the number of leukocytes adhering to glucose-treated HUVEC under flow conditions indicates that glucose-induced leukocyte adhesion to endothelium is associated with an upregulation of endothelial surface expression of adhesive molecules, as also documented directly by confocal microscopy experiments.

Experimental evidence is available that expression of adhesive molecules is critically dependent by intracytoplasmic activation of NF-kB. Thus specific subunits of NF-kB differentially regulate gene expression of E-selectin, ICAM-1 and VCAM-1 in endothelial cells activated by inflammatory cytokines (45-47). Here we examined whether high glucose-induced upregulation of adhesive molecules were critically dependent by the activation of NF-kB. By electrophoretic mobility shift assay, we documented, for the first time, that the exposure of endothelial cells to $30 \mathrm{mM}$ glucose induced an increase in NF-kB DNA binding activity. This finding together with data showing that specific inhibitors of NF-kB significantly reduced high glucose-induced leukocyte adhesion can be taken to suggest that hyperglycemia promoted upregulation of adhesive molecules through NF-kB activation. Since it has been documented that elevated glucose concentrations caused endothelial cell dysfunction through the generation of free radicals $(32,48)$ that are known intracellular intermediates for NF-kB activation (49), it is also possible that in our experimental conditions oxidant stress consequent to hyperglycemia is responsible for the activation of NF-kB.

In this study, we have also shown that the PKC inhibitor staurosporine markedly decreased the number of leukocytes adhering to high glucose-treated cells. Moreover, using specific antisense oligodesoxynucleotides against PKC $\alpha$ and $\epsilon$, we observed a marked reduction in leukocyte adhesion induced by glucose, thus suggesting a role for both PKC isoforms in the observed phenomenon. In line with our finding is the recent demonstration that high glucose concentrations lead to an increased expression of PKC $\alpha, \beta$, and $\epsilon$ in vascular smooth muscle cells (50) and in porcine aortic endothelial cells (37). The recent evidence that $\mathrm{PKC}$ activation leads to dissociation of $\mathrm{NF}-\mathrm{kB} / \mathrm{IkB}$ complex allowing NF-kB to translocate to the nucleus and activate its target genes (51) would suggest the possibility of a link between PKC and NF-kB activation in glucoseinduced adhesive molecule expression.

Another finding of this study is that AGEs significantly enhanced the number of leukocytes adhering to endothelial cells under flow conditions. These observations can be explained by recent data that AGE-albumin or AGE-modified matrix protein upregulated the expression of adhesive molecules on endothelial cells (23). Moreover, AGEs by interacting with endothelial RAGE, enhanced the expression of cell associated VCAM-1 and released soluble VCAM-1 antigen into cell supernatant by induction of cellular oxidant stress and activation of NF-kB (14). Because these aldose-modified proteins accu- mulate in the vessel wall of diabetics in vivo in humans, such data may be relevant to the pathogenesis of vascular complications associated with diabetes.

The definitive demonstration that both high glucose and AGEs directly affect leukocyte-endothelium interaction arises from the last observation of this study - that sera from diabetic patients with hyperglycemia and abnormal $\mathrm{HbA}_{1 \mathrm{c}}$ markedly enhanced the number of adhering leukocytes to endothelial cells in respect to sera taken from healthy subjects. Finding that IL-1 $\beta$ and $\mathrm{TNF} \alpha$ content in sera from diabetic patients was within the normal range would exclude a contribution of these cytokines in the stimulatory activity of diabetic sera.

In conclusion, our results indicate that $(a)$ high glucose concentration is a potent promoter of leukocyte adhesion to endothelial cells under flow conditions; $(b)$ glucose-induced leukocyte adhesion is dependent by upregulation of adhesion molecules, i.e., E-selectin, ICAM-1, and VCAM-1 as documented by confocal microscopy analysis and by inhibition studies with the respective specific antibodies; (c) NF-kB and PKC intracellular pathways are possibly involved in leukocyte-endothelium interaction in hyperglycemia; (d) AGEs significantly enhanced leukocyte attachment to endothelial cells; and $(e)$ sera from diabetic patients with elevated glycemia and abnormal $\mathrm{HbA}_{1 \mathrm{c}}$ induced a significant adhesive response as compared with sera from normal subjects. These findings might be relevant in understanding the nature of microvascular lesions associated to diabetes.

\section{Acknowledgments}

The authors thank Federica Casiraghi for performing cytokine measurement, and are grateful to Dr. Piero Ruggenenti for providing sera of diabetic patients. The authors are also indebted to Dr. Aldo Gambarini and Dr. Paola Rosaschino of the Division of Obstetrics and Gynecology, Ospedale Bolognini, Seriate, Bergamo, Italy, for invaluable help in collecting umbilical cord samples.

S. Angioletti is a recipient of fellowship from "Fondazione A. e A. Valenti;" Dr. R. Donadelli is a recipient of a fellowship from "Collegio dei Ragionieri e Periti Commerciali di Bergamo."

\section{References}

1. Ruderman, N.B., J.R. Williamson, and M. Brownlee. 1992. Glucose and diabetic vascular disease. FASEB J. 6:2905-2914.

2. Kinoshita, J.H., and C. Nishimura. 1988. The involvement of aldose reductase in diabetic complication. Diabetes Metab. Rev. 4:323-337.

3. Porte, D., Jr., and M.W. Schwartz. 1996. Diabetes complications: why is glucose potentially toxic? Science. 272:699-701.

4. Lee, T.-S., L.C. MacGregor, S.J. Fluharty, and G.L. King. 1989. Differential regulation of protein kinase $\mathrm{C}$ and $(\mathrm{Na}, \mathrm{K})$-adenosine triphosphatase activities by elevated glucose levels in retinal capillary endothelial cells. J. Clin. Invest. 83:90-94.

5. Vlassara, H. 1992. Receptor-mediated interactions of advanced glycosylation end products with cellular components within diabetic tissues. Diabetes. 41(Suppl. 2):52-56.

6. Vlassara, H., R. Bucala, and L. Striker. 1994. Pathogenic effects of advanced glycosylation: biochemical, biologic, and clinical implications for diabetes and aging. Lab. Invest. 70:138-151.

7. Bucala, R., and H. Vlassara. 1995. Advanced glycosylation end products in diabetic renal and vascular disease. Am. J. Kidney Dis. 26:875-888.

8. Kirstein, M., J. Brett, S. Radoff, S. Ogawa, D. Stern, and H. Vlassara. 1990. Advanced protein glycosylation induces transendothelial human monocyte chemotaxis and secretion of platelet-derived growth factor: role in vascular disease of diabetes and aging. Proc. Natl. Acad. Sci. USA. 87:9010-9014.

9. Schmidt, A.M., S.D. Yan, J. Brett, R. Mora, R. Nowygrod, and D. Stern. 1993. Regulation of human mononuclear phagocyte migration by cell surfacebinding proteins for advanced glycation end products. J. Clin. Invest. 91:21552168.

10. Vlassara, H., M. Brownlee, K.R. Manogue, C.A. Dinarello, and A. 
Pasagian. 1988. Cachectin/TNF and IL-1 induced by glucose-modified proteins: role in normal tissue remodeling. Science. 240:1546-1548.

11. Neeper, M., A.-M. Schmidt, J. Brett, S.-D. Yan, F. Wang, Y.-C. Pan, K. Elliston, D. Stern, and A. Shaw. 1992. Cloning and expression of RAGE: a cell surface receptor for advanced glycation endproducts of proteins. J. Biol. Chem. 267:14998-15004.

12. Brett, J., A.-M. Schmidt, Y.-S. Zou, S.-D. Yan, E. Weidman, D. Pinsky, M. Neeper, M. Przysiecki, A. Shaw, A. Migheli, and D. Stern. 1994. Tissue distribution of RAGE: expression in smooth muscle, cardiac myocytes, and neural tissue in addition to the vasculature. Am. J. Pathol. 143:1699-1712.

13. Vlassara, H., H. Fuh, Z. Makita, S. Krungkrai, A. Cerami, and R. Bucala. 1992. Exogenous advanced glycosylation end products induce complex vascular dysfunction in normal animals: a model for diabetic and aging complications. Proc. Natl. Acad. Sci. USA. 89:12043-12047.

14. Schmidt, A.-M., O. Hori, J.X. Chen, J.F. Li, J. Crandall, J. Zhang, R. Cao, S.D. Yan, J. Brett, and D. Stern. 1995. AGEs interacting with their endothelial receptor induce expression of VCAM-1 in cultured human endothelial cells and in mice. J. Clin. Invest. 96:1395-1403.

15. Dosquet, C., D. Weill, and J.L. Wautier. 1992. Molecular mechanism of blood monocyte adhesion to vascular endothelial cells. Nouv. Rev. Fr. Hematol. 34:S55-S59.

16. Hadcocks, S., M. Richardson, P. Winocour, and M.W.C. Hatton. 1991. Intimal alterations in the first six months of alloxan-induced diabetes. Arterioscler. Thromb. 11:517-529.

17. Schroder, S., W. Palinski, and G. Schmid-Schonbein. 1991. Activated monocytes and granulocytes, capillary nonperfusion, and neovascularization in diabetic retinopathy. Am. J. Pathol. 139:81-100.

18. Yang, X.-D., S.A. Michie, R.E. Mebius, R. Tisch, I. Weissman, and H.O. McDevitt. 1996. The role of cell adhesion molecules in the development of IDDM. Implications for pathogenesis and therapy. Diabetes. 45:705-710.

19. Hanninen, A., S. Jalkanen, M. Salmi, S. Toikkanen, G. Nikolakaros, and O. Simell. 1992. Macrophages, T cell receptor usage, and endothelial cell activation in the pancreas at the onset of insulin-dependent diabetes mellitus. J. Clin. Invest. 90:1901-1910.

20. McLeod, D.S., D.J. Lefer, C. Merges, and G.A. Lutty. 1995. Enhanced expression of intracellular adhesion molecule-1 and P-selectin in the diabetic human retina and choroid. Am. J. Pathol. 147:642-653.

21. Kim, J.A., J.A. Berliner, R.D. Natarajan, and J.L. Nadler. 1994. Evidence that glucose increases monocyte binding to human aortic endothelial cells. Diabetes. 43:1103-1107.

22. Haller, H., Y. Groschek, and F.C. Luft. 1994. Glucose induces increased surface expression of adhesion molecules VCAM-1 and ELAM-1 on endothelial cells via activation of protein kinase C. J. Am. Soc. Nephrol. 5:965 (Abstr.).

23. Sengoelge, G., J. Menzel, W. Druml, and G. Sunder-Plassmann. 1995. Glycated matrix proteins increase the expression of adhesion molecules on endothelial cells. J. Am. Soc. Nephrol. 6:1048 (Abstr.)

24. Lawrence, M.B., L.V. McIntire, and S.G. Eskin. 1987. Effect of flow on polymorphonuclear leukocyte/endothelial cell adhesion. Blood. 70:1284-1290.

25. Lawrence, M.B., C.W. Smith, S.G. Eskin, and L.V. McIntire. 1990. Effect of venous shear stress on CD18-mediated neutrophil adhesion to cultured endothelium. Blood. 75:227-237.

26. Morigi, M., C. Zoja, M. Figliuzzi, M. Foppolo, G. Micheletti, M. Bontempelli, M. Saronni, G. Remuzzi, and A. Remuzzi. 1995. Fluid shear stress modulates surface expression of adhesion molecules by endothelial cells. Blood. 85:1696-1703.

27. Ley, K., D.C. Bullard, M.L. Arbonés, R. Bosse, D. Vestweber, T.F. Tedder, and A.L. Beaudet. 1995. Sequential contribution of L- and P-selectin to leukocyte rolling in vivo. J. Exp. Med. 181:669-675.

28. Lawrence, M.B., and T.A. Springer. 1993. Neutrophils roll on E-selectin. J. Immunol. 151:6338-6346.

29. Wuthrich, R.P. 1992. Intercellular adhesion molecules and vascular cell adhesion molecule-1 and the kidney. J. Am. Soc. Nephrol. 3:1201-1211.

30. Brady, H.R. 1994. Leukocyte adhesion molecules and kidney diseases. Kidney Int. 45:1285-1300.

31. Jaffe, E., R. Nachman, C. Becker, and C. Minick. 1973. Culture of human endothelial cells derived from umbilical veins; identification by morpho- logic and immunologic criteria. J. Clin. Invest. 52:2745-2756.

32. Kashiwagi, A., T. Asahina, Y. Nishio, M. Ikebuchi, Y. Tanaka, R. Kikkawa, and Y. Shigeta. 1996. Glycation, oxidative stress, and scavenger activity. Glucose metabolism and radical scavenger dysfunction in endothelial cells. Diabetes. 45(Suppl. 3):S84-S86.

33. Orthner, C.L., G.M. Rodgers, and L.A. Fitzgerald. 1995. Pyrrolidine dithiocarbamate abrogates tissue factor (TF) expression by endothelial cells: evidence implicating nuclear factor-kB in TF induction by diverse antagonists. Blood. 86:436-443.

34. Rovin, B.H., J.A. Dickerson, L.C. Tan, and C.A. Hebert. 1995. Activation of nuclear factor-kB correlates with MCP-1 expression by human mesangial cells. Kidney Int. 48:1263-1271.

35. Henkel, T., T. Machleidt, I. Alkalay, M. Kronke, Y. Ben-Neriah, and P.A. Baeuerle. 1993. Rapid proteolysis of IkB- $\alpha$ is necessary for activation of the transcriptional factor NF-kB. Nature. 365:182-185.

36. Mitsumata, M., R.S. Fishel, R.M. Nerem, R.W. Alexander, and B.C. Berk. 1993. Fluid shear stress stimulates platelet-derived growth factor expression in endothelial cells. Am. J. Physiol. 265:H3-H8.

37. Hempel, A., C. Maasch, U. Heintze, C. Lindschau, R. Dietz, F.C. Luft, and H. Haller. 1997. High glucose concentrations increase endothelial cell permeability via activation of protein kinase C $\alpha$. Circ. Res. 81:363-371.

38. Koenig, R.J., C.M. Peterson, R.L. Jones, C. Saudek, M. Lehrman, and A. Cerami. 1976. Correlation of glucose regulation and hemoglobin A1c in diabetes mellitus. N. Engl. J. Med. 295:417-420.

39. Takata, K., S. Horiuchi, N. Araki, M. Shiga, M. Saitoh, and Y. Morino. 1988. Endocytic uptake of nonenzymatically glycosylated proteins is mediated by a scavenger receptor for aldehyde-modified proteins. J. Biol. Chem. 263: 14819-14825.

40. Macconi, D., M. Foppolo, S. Paris, M. Noris, S. Aiello, G. Remuzzi, and A. Remuzzi. 1995. PAF mediates neutrophil adhesion to thrombin or TNFstimulated endothelial cells under shear stress. Am. J. Physiol. 269:C42-C47.

41. Satriano, J., and D. Schlondorff. 1994. Activation and attenuation of transcription factor NF-kB in mouse glomerular mesangial cells in response to tumor necrosis factor- $\alpha$, immunoglobulin $G$, and adenosine $3^{\prime}: 5^{\prime}$-cyclic monophosphate. J. Clin. Invest. 94:1629-1636.

42. Wallenstein, S., C.L. Zucker, and J.L. Fleiss. 1980. Some statistical methods useful in circulation research. Circ. Res. 47:1-9.

43. Lawrence, M.B., and T.A. Springer. 1991. Leukocytes roll on a selectin at physiologic flow rates: distinction from and prerequisite for adhesion through integrins. Cell. 65:859-873.

44. Panés, J., I. Kurose, D. Rodriguez-Vaca, D.C. Anderson, M. Miyasaka, P. Tso, and N. Granger. 1996. Diabetes exacerbates inflammatory responses to ischemia-reperfusion. Circulation. 93:161-167.

45. Read, M.A., M.Z. Whitley, A.J. Williams, and T. Collins. 1994. NF-kB and $\operatorname{IkB} \alpha$ : an inducible regulatory system in endothelial activation. J. Exp. Med. 179:503-512.

46. Ledebur, H.C., and T.P. Parks. 1995. Transcriptional regulation of the intercellular adhesion molecule-1 gene by inflammatory cytokines in human endothelial cells. Essential roles of a variant NF-kB site and p65 homodimers. $J$. Biol. Chem. 270:933-943.

47. Shu, H.B., A.B. Agranoff, E.G. Nabel, K. Leung, C.S. Duckett, A.S Neish, T. Collins, and G.J. Nabel. 1993. Differential regulation of Vascular cell adhesion molecule 1 gene expression by specific NF-kB subunits in endothelial and epithelial cells. Mol. Cell. Biol. 13:6283-6289.

48. Tesfamariam, B., and R.A. Cohen. 1992. Free radicals mediate endothelial cell dysfunction caused by elevated glucose. Am. J. Physiol. 263:H321H326.

49. Schreck, R., K. Albermann, and P.A. Baeuerle. 1992. Nuclear factor kB: an oxidative stress-responsive transcription factor of eucaryotic cells (a review). Free Rad. Res. Comms. 17:221-237.

50. Haller, H., E. Baur, P. Quass, M. Behrend, C. Lindschau, A. Distler, and F.C. Luft. 1995. High glucose concentrations and protein kinase $\mathrm{C}$ isoforms in vascular smooth muscle cells. Kidney Int. 47:1057-1067.

51. Ghosh, S., and D. Baltimore. 1990. Activation in vitro of NF-kB by phosphorylation of its inhibitor IkB. Nature. 344:678-682. 